\title{
Managing English Young Learners' Classroom Activities through Gestures: A Multimodal Perspective
}

\author{
Widia Yunita ${ }^{\circledR}$, Fuad Abdullah ${ }^{2}$, Meli Mellan², Arini Nurul Hidayati², Havid Ardi ${ }^{1}$ \\ Ilmu Keguruan Bahasa, Universitas Negeri Padang, Indonesia(1) \\ Pendidikan Bahasa Inggris, Universitas Siliwangi, Indonesia(2) \\ DOI: $\underline{10.31004 / \text { obsesi.v6i4.2007 }}$
}

\begin{abstract}
Managing classroom activities in children has become a challenge for English as a Foreign Language (EFL) teachers. Teachers usually use gestures in class activities, such as giving directions and pointing at students. This study explores the multimodal representation of the teacher's gestures when managing classroom activities in the EYL context. Data were collected through non-participant observation and analyzed by Systemic Functional Multimodal Discourse Analysis (SFMDA). The findings show that four meanings are multimodally represented in teacher gestures, namely (1) building student-teacher relationships through clapping and thumbs up, (2) emphasizing instruction through raising hands, pointing and lifting class objects, (3) encouraging involvement of students in academic tasks through finger pointing and counting down, and (4) warning of disruptive behavior of students through pulling gestures. Pedagogically, this research provides a paradigm shift that classroom-based communication does not have to use a single semiotic source but also a combination of other semiotic sources to help students understand teacher instructions easily.
\end{abstract}

Keywords: classroom management; gestures; multimodal perspective; teaching english to young learners (teyl).

\begin{abstract}
Abstrak
Mengelola kegiatan kelas pada anak-anak telah menjadi tantangan bagi guru Bahasa Inggris sebagai Bahasa Asing (EFL). Guru biasanya menggunakan gerak tubuh dalam kegiatan kelas, seperti memberikan arahan dan menunjuk siswa. Penelitian ini menggali representasi multimodal dari gerak tubuh guru saat mengelola kegiatan kelas dalam konteks EYL. Data dikumpulkan melalui observasi non partisipan dan dianalisis dengan Systemic Functional Multimodal Discourse Analysis (SFMDA). Temuan menunjukkan empat makna yang diwakili secara multimodal dalam gerak tubuh guru, yaitu (1) membangun hubungan siswa-guru melalui bertepuk tangan dan mengacungkan jempol, (2) menekankan instruksi melalui mengangkat tangan, menunjuk dan mengangkat benda-benda kelas, (3) mendorong keterlibatan siswa dalam tugas akademik melalui gerakan jari menunjuk dan menghitung mundur, dan (4) memperingatkan perilaku mengganggu siswa melalui gerakan menarik. Secara pedagogis, penelitian ini memberikan perubahan paradigma bahwa komunikasi berbasis kelas tidak harus menggunakan sumber semiotik tunggal tetapi juga kombinasi sumber semiotik lainnya untuk membantu siswa memahami instruksi guru dengan mudah. Kata Kunci: manajemen kelas; gestur; perspektif multimodal; mengajar bahasa inggris untuk anak
\end{abstract}

Copyright (c) 2022 Widia Yunita, et al.

$\triangle$ Corresponding author :

Email Address : widiayunita136@gmail.com (Riau, Indonesia)

Received 25 September 2021, Accepted 23 January 2022, Published 12 February 2022 


\section{INTRODUCTION}

Classroom management is viewed as a standout amongst the most imperative parts of teaching (Schneiderová, 2014). This pedagogical strategy functions to organize the classroom teaching and learning practices to attain the desired atmosphere (e.g. students' language learning engagement and awareness). In an extraordinary sense, it can be said that successful teaching and learning in English for young learners (henceforth, EYL) comes from effective classroom management (Qinglan et al., 2010). Managing English for young learners' (EYL) classroom activities has become challenging for teachers. It causes young learners (henceforth, YLs) to have different characteristics, such as dislikes, criticism, low concentration spans and very limited attention (Schneiderova, 2013). Hence, they can be easily unfocused, get bored and lose interests. Unfortunately, a majority of teachers tend to ignore the significance of classroom management. They may prefer to only emphasize on how teaching materials are delivered and how students cognitively understand them. In fact, successful teaching and learning activities do not only rely on their cognitive engagement but also behavioral, emotional and social engagement. By doing so, students do not only foster their cognition but also their behavior, emotion and social interaction. Therefore, to teach them effectively, teachers should be aware of these distinctions fitting to these age levels just as the procedures and activities to be implemented in the classroom (Cakir, 2004).

Teaching English to young learners (hereafter, TEYL) has become its own field of study as the age of compulsory. (Slattery \& Willis, 2001) state that young learners (henceforth, YLs) are children between 7-12 years old. In foreign language learning, there should be a certain method and technique required by a teacher in efforts to achieve the teaching and learning targets (Sukirmiyad, 2017). Since language lessons can be troublesome for YLs, teachers' responsibility is to make them interesting, lively and joyful (Kurniawati et al., 2017). In other words, keeping enjoyment in the class remains very positive for language learning. In such a case that students need to proceed with an action for quite a while, it will give them more exposures to language input and more opportunities to rehearse the learned language (Cakir, 2004). It needs to be addressed that teaching English to young learners brings a lot of responsibilities on the shoulders of the teachers in the classroom from structuring the materials to actualise them appropriately (Cakir, 2004).

Learning activities ought to be pleasant and supportive for generating the enthusiasm of the students as long as it takes them to prevail in what they are doing (Phiri, 2016). Teachers dependably use gestures in classroom activities, such as giving commands or directions, appointing students and giving instructions (Kusanagi, 2015). It is believed that utilising gestures in the classroom can enhance correspondence between the teacher and students. Also, it empowers students in the learning process (Davies, 2003). (Jakšić, 2017) states that teachers should obtain appropriate knowledge about gestures to expand the extent of communication. This is to enable them in delivering teaching materials effectively and to eliminate potential issues in the transmission of a message.

Gestures are hand movements occurring naturally that have a message to deliver and are produced during the moment of speaking (Scherr, 2008). On another argument, (McNeill, 1992) argues that gestures are an integral part of language as much as are words, phrases, and sentences gesture and languages are one system. (Kendon, 1996) proposes that a gesture consists of phases of bodily action possessing those characteristics that permit them to be recognised as components of willingness to communicate. Utilising gestures is a key resource for meaning-making in the Greek rhetoric (F. V. Lim, 2011).

Practically speaking, the teachers commonly employ gestures to point out concrete objects or actions (iconic), communicate abstract objects or actions (metaphors), denote or direct an event (deictic) and produce a rhythmic beat without having a semantic meaning (beat) (McNeill, 1992). Previous studies have investigated the roles and functions of the teacher's gestures in the classroom. Identified the functions of gestures including "Three key functions, namely gestures as comprehension aids, gestures for classroom management and gestures 
influencing learners' affect and classroom atmosphere" (Kusanagi, 2015). In (Sime, 2006) study, there are three functions of the second language (henceforth, L2) teachers' gestures, namely cognitive, organisational, and emotional. Similarly, Kita (2000) suggested the three functions of other-directed gestures in the first language (henceforth, L1) conversation. They are delivery of content, speech regulation and affect. Therefore, gestures have significant functions during communication in education, notably in the classroom activities.

Even though the gesture studies have been popularly recognised as one of investigative foci in communication research, studies on gesture have not yet been widely recognised in the fields of Applied Linguistics or Language Education (Gullberg \& McCafferty, 2008). The integration of speech and gestures in analyses of a L2/foreign language (FL) discourse can help understand more about Second Language Acquisition/Foreign Language Acquisition (hereafter, SLA/FLA) in a classroom setting as numerous applied linguists have proposed (Gullberg, 1998). Hence, by scrutinizing gestures, it is expected to provide teachers more knowledge about the roles of gestures in language education.

Theoretically speaking, gestures belong to a semiotic resource viewed from the multimodal perspective (multimodality). Multimodality refers to the process of meaningmaking which intersemiotically involve various semiotic resources, such as language, visual images, gestures, space, movement, audio, audiovisual, etc (Thibault, 2000). This perspective has significantly changed an array of learning, notably language learning in which students are guided to have a multimodal learning experiences by activating their sensory modalities (e.g. seeing, smelling, touching, moving, etc.) while engaging in the classroom activities (Abdullah, 2018; F. V. Lim, 2011). As a result, implementing a multimodal approach (e.g., gestures in English language teaching) remains crucial to help teachers convey the teaching materials and students understand them effectively.

A plethora of studies have examined the roles of gestures in the classroom, such as investigation of the roles and functions of teacher's gestures in foreign language teaching (Kusanagi, 2015), gestures in teaching pronunciation (Smotrova, 2017), analysing the teachers' use of gestures in the classroom (F. V. Lim, 2011; Sime, 2006), language ideologies on the difference between gesture and sign (Kusters \& Sahasrabudhe, 2018), effects of gestures in providing oral corrective feedback (Sato, 2019), teachers' gestures on their second language (L2) utterances in EFL lessons (Sato, 2020), teachers' gestures in elementary literacy classrooms in China (Bowcher \& Zhang, 2020) and functional classification of pragmatic gestures (Lopez-Ozieblo, 2020), scarce research has focused on the meanings of teacher's gestures in managing EYL classroom activities. To fill this void, the present study emphasizes the multimodal representation of teacher's gestures while managing classroom activities in EYL context.

The predominant consideration of adapting SFMDA as an analytical perspective since it allows the researchers not only to analyze a single semiotic source (e.g. language) but also a combination of them (e.g. linguistic, visual, gestural, audio, audiovisual, etc.) to understand how the teacher and students made meaning.

\section{METHODOLOGY}

The present study employed classroom research. This study attempted to analyse natural-occurring phenomena in the language classroom (Hopkins, 2008). Technically, this study was conducted at a private elementary school in Tasikmalaya, West Java, Indonesia. The participant of this study was an English teacher of second grade. He was a teacher of the school's recommendations to be recruited as a participant because of his well-established skills in managing classroom activities. Currently, he teaches three English language classes for six hours a week. The researcher selected purposively one of the classes as an investigative focus. The class was selected due to the students' positive engagement, willingness to participate in the scrutiny and accessibility. The class was a second grade comprising 30 students. 
The data were collected through non-participant observation. The observation was performed to record the entire activities occurring in the EYL classroom through video recording. States that video recording provides contextual data by showing what really took place in the classroom (Dufon \& others, 2002). The use of video recording enables the researcher to play the events repeatedly and see which parts had not been seen on the previous viewing. Replaying the videos then gives more time to analyse the data and avoiding a premature interpretation. After the observation, the researcher conducted framing for selecting the data that were suitable with communicative gestures. The researcher also collected the data of teacher's utterances through selecting spoken linguistic evidence (clauses) that accompany gestures to be analysed. The data were analysed using SFMDA (V. F. Lim, 2019) and Transitivity (Eggins, 2004; Halliday et al., 2014; Matthiessen, 1999).

On the whole, the steps of this study encompassed identifying the investigative issue or problem, reviewing literature, formulating research question(s), determining the aim(s) of the study, collecting and analyzing the data and producing a research report.

\section{FINDINGS AND DISCUSSION}

\section{Building a student-teacher relationship through clapping hand and giving thumbs up Providing appreciation through clapping hands}

One of the gestures produced by the teacher to build a positive relationship with his students is through clapping hands. This gesture was carried out as a response to one of his students (F) willing to be a leader of a classroom learning group. As a matter of fact, figure 2 deciphers that the teacher was lifting his both hands and shaping clapping hands gesture against his students. In a similar vein, his students imitated him to clap their hands as instructed by him. Verbally, he uttered "Tepuk tangan untuk F [applaud for F]" to emphasize his instruction to provide hand clapping for one of their classmates. Contextually, the teacher also deployed such a hand gesture as a sign to motivate and appreciate his students after they correctly responded to his questions. Contends that this gesture and language production belong to Language Correspondent Gestures where it is semantically accompanied by a language to affirm the delivery of a message ( Lim, 2019).

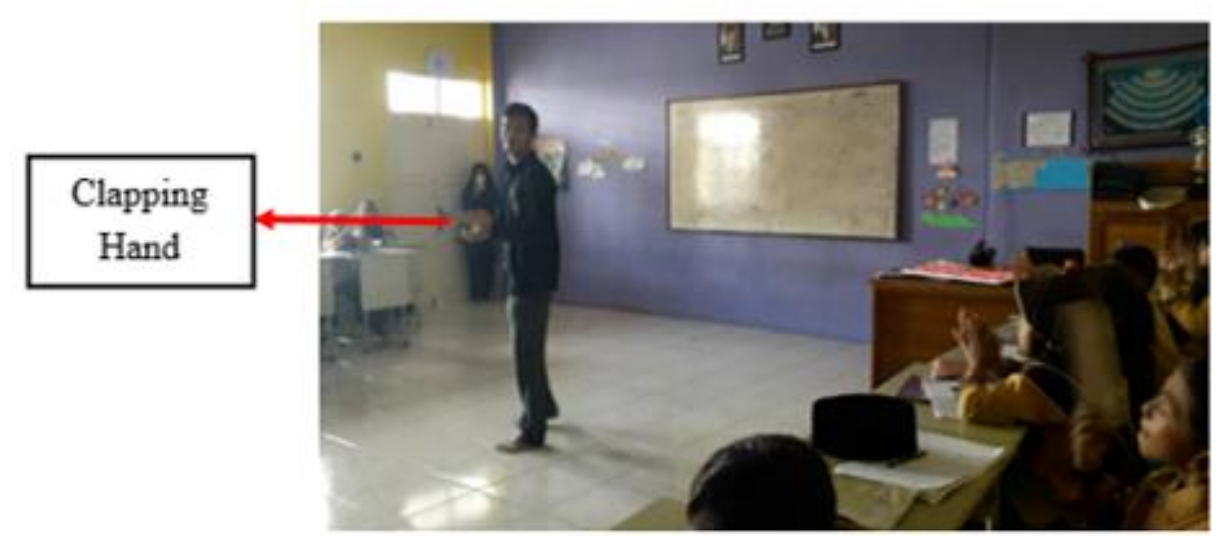

Figure 1. Showing appreciation through clapping hands

From Figure 1, it can be inferred that the teacher was trying to take the students' attention by clapping his hands. Viewed from Systemic Functional Linguistic (SFL) lens, the teacher's utterance consists of a material process, namely the word 'applaud'. More specifically, applauding is classified as the material process since it represents a physical activity of hitting open hands simultaneously several times to display approval, appreciation or enjoyment. Halliday et al. (2014) add that a material clause construes of doings and happenings, including actions, activities, and events. In this case, the teacher attempted to appreciate and encourage his students to be more confident and engaged in the classroom learning activities through 
such a hand gesture. Likewise, he generated his students' social awareness to have a sense of appreciation to others' attainments. Notes that gestures and facial expressions provide social functions, such as demonstrating politeness, respect and formality to interlocutors. Nevertheless, even though nonverbal communication (e.g. gestures) offers informative clues to what speakers mean and reinforces what they utter or perceive, the dissimilar cultural context in communication may lead to multifaceted interpretations (Shearman et al., 2011)

\section{Providing praise through thumbs up}

Another gesture performed by the teacher is giving thumbs up. He produced such a gesture to give praise to his students who were able to answer his questions correctly. Figure 3 depicts that he gave thumbs up to a number of the students responding his questions which were accompanied by a typical Upin and Ipin's well-known jargon, namely betul, betul betul [correct, correct, correct]. Though the teacher utilized his fingers frequently while teaching English to his students, it did not mean that he positioned himself more superior than his students. He used the fingers to provide the students cues in comprehending the delivered teaching materials (e.g. English classroom objects or properties).

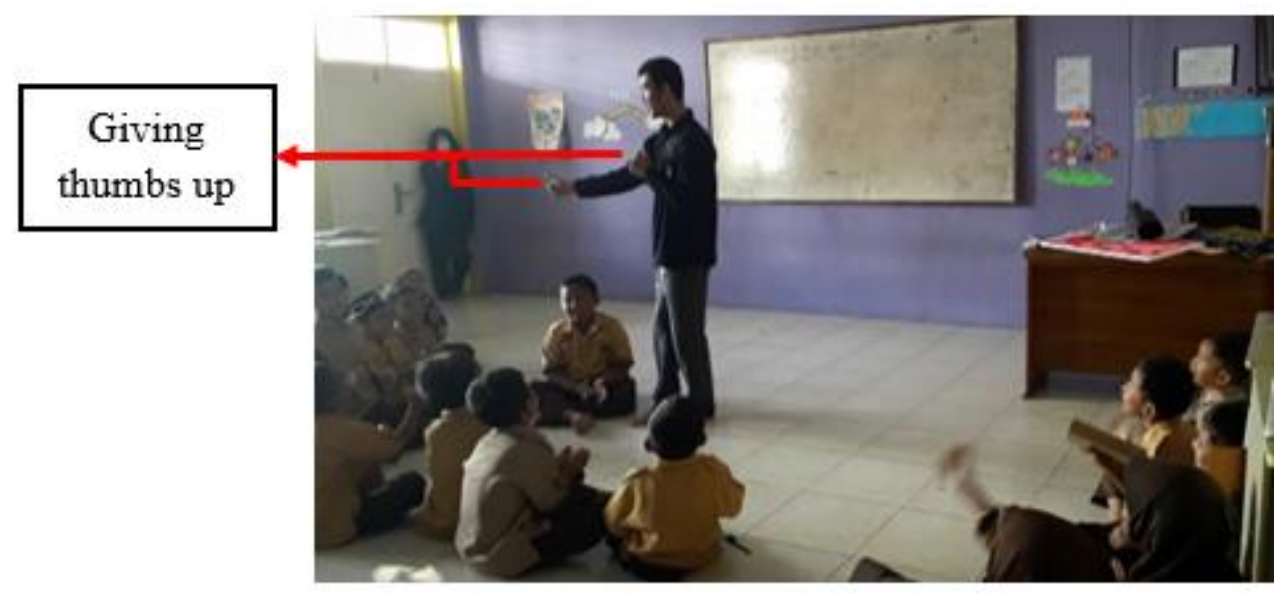

Figure 2. Providing praise through thumbs up

Figure 2 depicts a situation in which the teacher put his thumbs up to appreciate one of his students. Contextually speaking, giving thumbs up was a part of his classroom instructional gestures commonly carried out, namely Upin and Ipin hand clapping. Giving thumbs up is regularly produced as the last hand movements of Upin and Ipin hand clipping. Specifically, this gesture is the main point of doing Upin and Ipin hand clipping.

The teacher routinely performed Upin and Ipin hand clapping to manage his students to keep engaged during teaching and learning practices. Upin and Ipin hand-clapping was originated from a Malaysian cartoon telling popular twin children, their family and friends. He adapted Upin and Ipin as a common instructional gesture because both Malaysian cartoon figures enable to attract the students' attention from their behavioural and verbal acts (e.g., hand-clapping, articulating betul, betul, betul and giving thumbs up) in which they remain easily identified from their widespread movie. Concerning the selection of this cartoon movie, he claimed that Upin and Ipin is one of the most familiar cartoon figures extensively recognized by Indonesian children instead of other cartoon characters (Personal Communication, January $5^{\text {th }}$ 2022).

Asserts that Upin and Ipin is a short animation popularly recognised not only in Malaysia but also in other Asia neighbouring countries such as Indonesia, Brunei, Singapore, and the Philippines (Ghani \& Bin, 2015). By doing this, the students could keep focused and engaged throughout classroom learning activities (Shin \& Crandall, 2014). In short, although the teacher did not express his praise verbally to his students, they were able to capture the 
message implicitly represented from his nonverbal cues (e.g., thumbs up represented as giving praise).

Further, (Aigner et al., 2012) claim that thumbs-up was commonly assumed to indicate 'good job, all right, stop now'. In this case, the gesture was addressed to several students as a sign of congratulations. Also, such a gesture belongs to Language Dependent Gesture as a part of Indexical Action. Indexical Action realises Ideational Meaning where a meaning is made through accompanying language ( Lim, 2019). He also added that Language Dependent Gestures function to enhance the information for more sensible interpretations (e.g., a beat of the arm in tandem with speech). As a result, giving thumbs up supplies positive impacts on students' learning performances and a good social relationship though it is only a small gestural action. Even, it builds positive discourses among teacher and students' relationships, such as friendliness, approval or solidarity (Abdullah, 2018; Attwood et al., 1988).

\section{Emphasizing the instructions through raising hands, pointing and raising classroom objects}

To manage the classroom activities effectively, the teacher deployed assorted gestures, such as raising a right hand (figure 4), pointing (figure 5) and utilising classroom objects (figure 6). To illustrate, the teacher raised his right hand to provide instructions to his students while articulating "Satu, satu [one by one].

\section{Emphasizing the instructions through raising the right hand}

To begin with, he raised his right hand and verbalized "Satu-satu" [one by one] to manage the students' turns while responding to his questions. This gesture cannot be comprehended clearly when he merely raised his right hand (see figure 3)

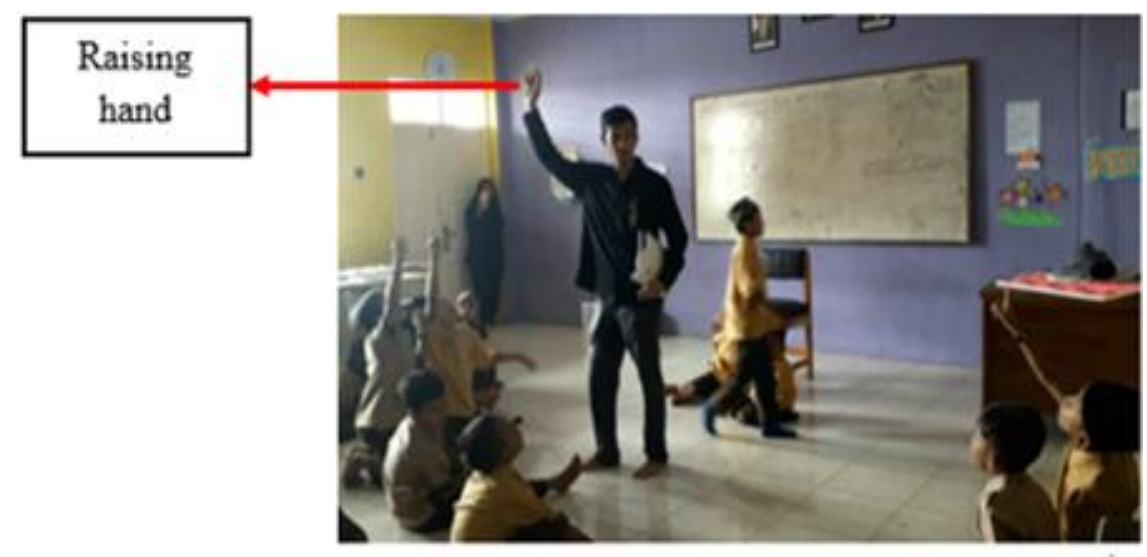

Figure 3. Giving instruction through raising the right hand

However, it turned obvious and understandable when he accompanied his gesture with a verbal cue, namely "Satu-satu" [one by one]. Theoretically, this sort of gesture belongs to the Language Dependent Gestures due to its dependency on a language to make meaning contextually ( Lim, 2019). As a result, the students complied with his instruction to raise their hands one by one before answering his questions. Contends that teachers can utilise gestures while providing instructions to help students understand their instructions (Corevelia, 2016). Similarly, Widharyanto \& Binawan (2020) report that most of the Indonesian students (e.g., Java, Papua, Flores, Dayak, and Batak ethnics) have bimodal (Aural-Kinesthetic) and trimodal (Read/Write-Visual-Aural) learning styles. Therefore, the employment of appropriate gestures remains crucial to avoid communication breakdowns and attain successful teaching practices. Dealing with this research context, hand raising gestures offer a valuable signifier for students to their teachers' classroom instructions effectively (Wiliam, 2011). 


\section{Emphasizing the instructions through pointing}

The teacher did not only raise his hands but also use pointing as an instructional gesture in the classroom. In this case, when the students engaged in a classroom quiz, he employed pointing gestures repeatedly to manage their interactional activities. For instance, Figure 4 showcases that the teacher gave instructions through pointing.

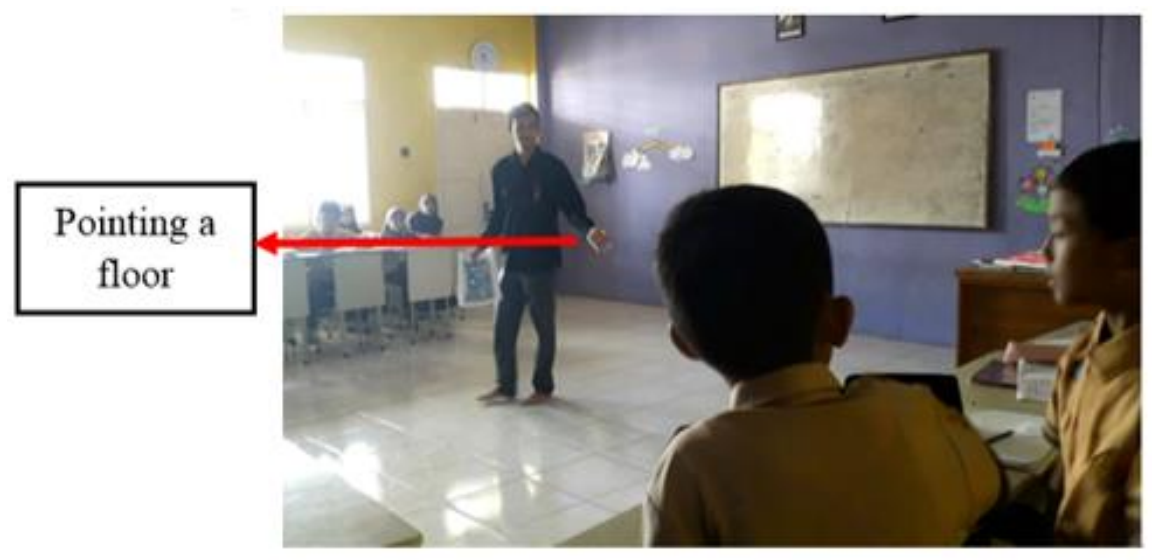

Figure 4. Giving instructions through pointing

He instructed a group of the students (team C) to move their seating places to a location pointed by him. To emphasize his instruction, he maintained "Tim C disini" [Team C is right here]. Multimodally, this combination of gestural and linguistic modes is categorised into Language Dependent Gestures because he complemented his pointing gesture (e.g. pointing to the floor over him) with a verbal cue (e.g. Tim C disini]. ( Lim, 2011; Martinec, 2000). Linguistically, grounded in transitivity analysis, the utterance "Tim C disini" [Team C is right here] can be broken down to be an existent (Team C), an existential process (is) and a circumstantial adjunct of location (right here) (Gerot \& Wignell, 1994; Halliday et al., 2014). Hence, the teacher's pointing gesture functions to mobilise his students from one place to another. Lim (2017) asserts that this occurrence can be classified to the representation of relationships of the pointed objects and the teacher's utterance. Given these facts, pointing gestures can effectively be deployed if they are accompanied by a language.

Emphasizing the instructions through utilising classroom objects

Deploying classroom objects becomes another predominant gesture performed by the teacher to optimise the effectiveness of classroom instructions. To illustrate, he employed classroom objects as instructional media (e.g. a pencil, a bag, and a board marker). As an example, he put a pencil under the chair and asked his students "Where is the pencil?" At the same time, he pointed to such a pencil to ensure that his students still focused on the same object (e.g. the pencil under the chair, not another pencil). Similarly, instructional practices were carried out with different classroom objects (e.g. a bag, a book, a board marker, and a pencil case) and diverse directions (e.g. above, front, back, right, left and other directions). These were aimed at building their knowledge about directions contextually. Viewed from a multimodal perspective, his teaching practices involving classroom objects with their various directions can be classified to the Language Dependent Gestures ( Lim, 2019; Martinec, 2000). It means that the teacher's gesture (pointing to a pencil) can be meaningfully understood if accompanied with a verbal cue (e.g. where is the pencil?). The main reason of why the teacher employed his gestures rather than other instructional media (e.g. whiteboard) because he tried to provide the best visualization of a classroom object position (e.g. a pencil on the floor). To visualize the situation, it is described in Figure 5. 


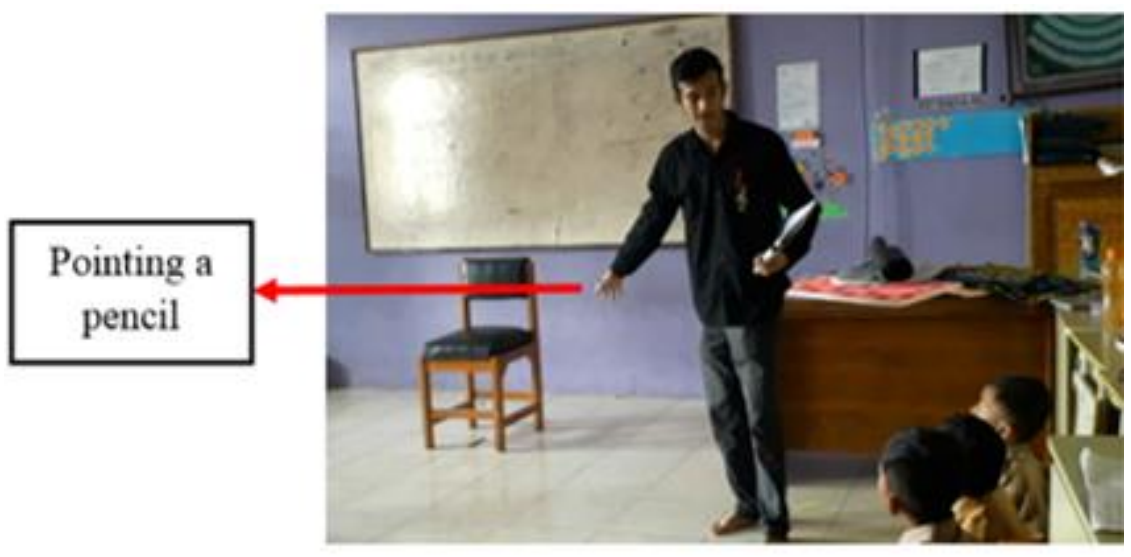

Figure 5. Giving instruction through pointing a pen

On the other hand, the utterance "Where is the pencil?" can be analysed as an attribute (where), attributive: circumstantial attributive (is) and carrier (the pencil). This utterance belongs to a relational process viewed from SFL-informed analytical framework (transitivity) (Halliday et al., 2014). With this in mind, applying classroom objects facilitates the students to maximise their understanding on teaching materials because they learned in a multisensory way ( Lim, 2019). Further, these activities provide self-efficacy for the teacher due to his skills to conduct effective classroom management.

\section{Encouraging Students' engagement in academic tasks by pointing and counting down finger movements}

One of the most prominent goals of teaching activities is to engage them in various classroom activities and tasks. Consequently, encouraging students' learning engagement remains vital. In this instance, the teacher performed two salient gestures, namely pointing and counting down finger movements.

To begin with, to engage students in classroom activities, the teacher produced pointing gestures. As an example, when the teacher was guiding his questions and answer session (Q/A session), he posed a question to his students to locate a classroom object, namely a book (e.g. where is the book?). One of the students raised her right hand as a response to the teacher's question. To follow up, he pointed to the student without verbalising anything. Gesturally, even though he did not provide any verbal cues to emphasize his response, the student can still understand what he meant, namely giving a chance for her to answer his question. Theoretically, this type of gesture is categorised as Language Dependent Gestures (Martinec, 2000) since the gestural meaning can be comprehended without being accompanied by a language. (Kendon, 1996) and (Cienki, 2008) add that Language Independent Gestures are gestures occurring without a statement and make meaning on their own. More specifically, this gesture is a part of Representing Action which has a signifying action (Martinec, 2000). Briefly stated, in this context, pointing gestures facilitate the teacher to encourage his students to answer the questions.

In addition to the use of pointing gestures, the teacher utilised counting down finger movements to emphasize students' responses on the given questions. For example, in the first session of a quiz, the teacher reminds his students about the duration for answering the questions. 


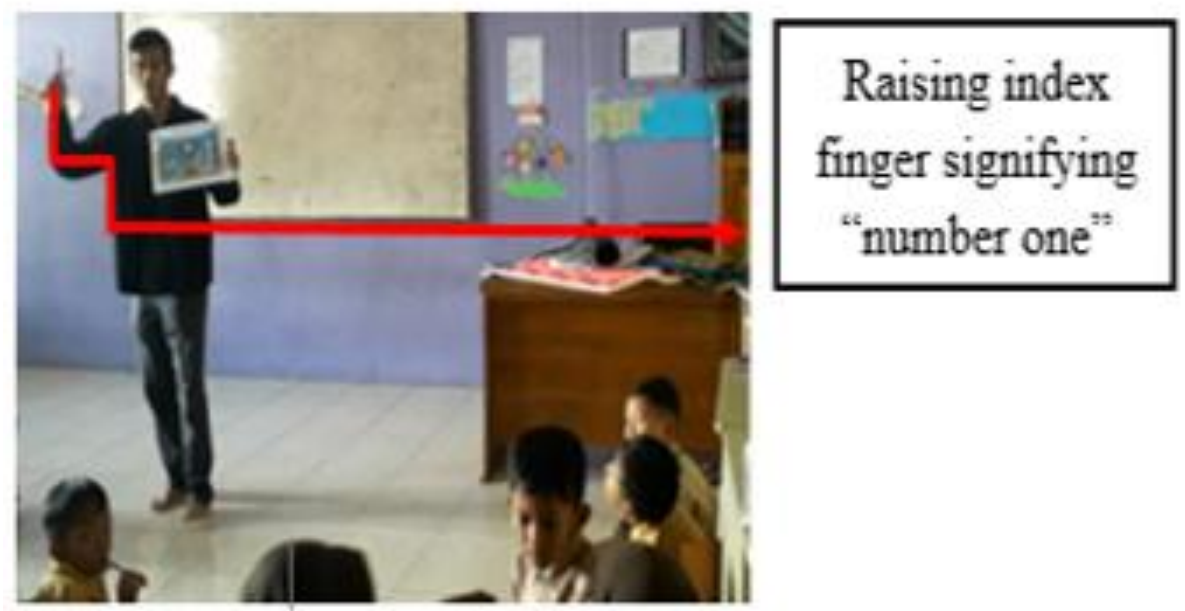

Figure 6. Encouraging students' engagement through counting down finger movements

Figure 6 denotes that the teacher shaped signs of number (e.g. number one and two). In this sense, he tried to remind his students that they merely possessed limited time to answer the questions. Gesturally, he performed counting down finger movements by using the index finger for number one and his index and middle fingers for number two. When he was producing such gestures, he uttered "one...two". These gestures belong to Language Correspondent Gestures (Lim, 2019) due to gestures and a language occur simultaneously and showed a coherent relationship. Given these facts, counting down finger movements encourage students to engage in academic tasks.

The teacher utilized his fingers while teaching the students since fingers are regarded as one of the most functional parts of the hands, particularly in the classroom-based activities of the young learners learning English. For instance, the teacher attempted to facilitate students in understanding an instruction of responding his question. McNeill (1992) mentions labels this type of gesture as Deictic gestures. Deictic gesture refers to a sort of gesture functioning to direct concrete or abstract things in a site.

\section{Warning students' disruptive behaviours through pulling movements}

The teacher performed pulling movement as a gesture to manage one of his students' disruptive behaviour in the classroom (e.g. sleeping in the classroom). In response to such a disruptive behaviour, he pulled his students' body and said "Duduk...duduk" [take a seat ... take a seat] (see Figure 7).

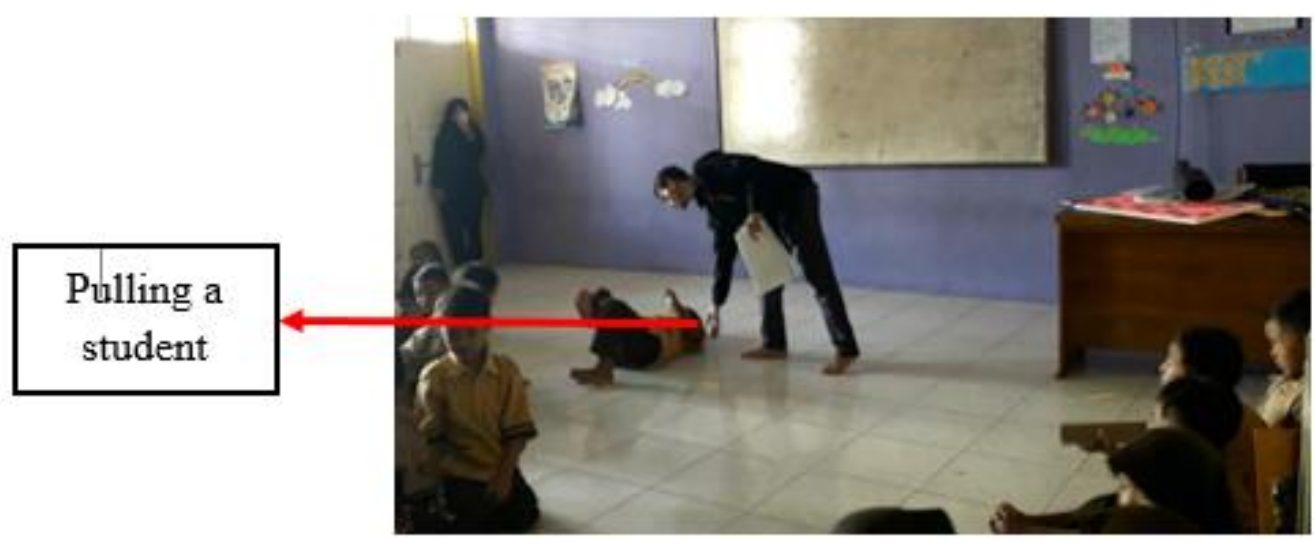

Figure 7. Warning a student using pulling movement 
This gesture is categorised into Language Dependent Gestures (Lim, 2019). It means that to understand the meaning of this gesture, language is required to gain a more accurate and contextual interpretation. Meanwhile, the utterance "Duduk...duduk [take a sit ... take a sit]" belongs to a material process (Halliday et al., 2014) because it represents an instruction for students to sit well as other students did. It became a warning for him to sit while learning in the classroom. Affirms that one of the ways to minimise the students' disruptive behaviours is through warning them (Al-Amarat, 2011). This warning-based gesture is interpreted as asahasih-asuh (teaching-loving-caring) pedagogical philosophy to improve character education in the Indonesian landscape (Sukendar et al., 2019). Asah (teaching) is aimed at fostering the intellectual ability of students. Asih (loving) is framed to inculcate good (noble) life values. Asuh (caring) is proposed to cultivate an autonomous personality (Sukendar et al., 2019). Hence, gestures can be an effective instructional technique to overcome the students' disruptive behaviours.

\section{CONCLUSION}

The study concludes that using gestures appropriately helps teachers manage EYL classroom activities because whenever gestures are exhibited suitably, teachers can arrange lessons easily. Although this study has offered new horizons on the roles of gestures in English language education, its limitations encompass the investigative focus and data collection technique. Further research can cover the entire types of gestures (e.g. facial expressions, body movements, etc.) to obtain more representative and holistic portrayal of the applications of gestures produced by English language teachers in the classroom. Moreover, interactive and compositional meanings of teachers' gestures can also be explored. Another limitation is the use of a single data collection technique (non-participant observation). The next study should encompass multifaceted data collection techniques, such as interview, stimulated recall, document analysis or administering questionnaires to gain more credible, dependable, transferable and confirmable data.

\section{ACKNOWLEDGMENT}

We would like to deliver our sincere appreciations to the participants involved in this study for their voluntarily participations.

\section{REFERENCES}

Abdullah, F. (2018). Social actors in an Intercultural Communication classroom: A discursive lens of intercultural education. Indonesian JELT, 13(1), 31-51. https:// doi.org/10.25170/ijelt.v13i1.1449

Abdullah, F., \& Lulita. (2018). Social actors in an intercultural communication classroom: A discursive lens of intercultural education. IJELT, 13(1), 31-51. https://doi.org/10.25170/ijelt.v13i1.1449

Aigner, R., Wigdor, D., Benko, H., Haller, M., Lindlbauer, D., Ion, A., Zhao, S., Tzu, J., \& Valino, K. (2012). Understanding Mid - Air Hand Gestures: A Study of Human Preferences in Usage of Gesture Types for HCI. Microsoft Research TechReport MSR-TR, 30(2).

Al-Amarat, M. S. (2011). The classroom problems faced teachers at the public schools in Tafila Province, and proposed solutions. International Journal of Educational Sciences, 3(1), 37-48. https:// doi.org/10.1080/09751122.2011.11890007

Attwood, A., Frith, U., \& Hermelin, B. (1988). The understanding and use of interpersonal gestures by autistic and Down's syndrome children. Journal of Autism and Developmental Disorders, 18(2), 241-257. https://doi.org/10.1007/BF02211950

Bowcher, W. L., \& Zhang, Z. (2020). Pointing at words: Gestures, language and pedagogy in elementary literacy classrooms in China. Linguistics and Education, 55, 100779. https://doi.org/10.1016/j.linged.2019.100779 
Cakir, I. (2004). Designing activities for young learners in EFL classrooms. Gazi Üniversitesi Gazi E $\{\backslash \mathrm{u}\{\mathrm{g}\}\}$ itim Fakültesi Dergisi, 24(3).

Cienki, A. (2008). Why study metaphor and gesture? In Metaphor and gesture (pp. 5-25). John Benjamins. https:// doi.org/10.1075/gs.3.04cie

Corevelia. (2016). Classroom instructions for young learners: A case study. (Unpublished Ph.D. thesis). Universitas Kristen Satya Wacana, Salatiga, Indonesia.

Davies, L. (2003). Effective Praise. Retrieved from Http://Www.Kellybear.Com/TeacherArticles/TeacherTip37.Html, 20, 2013.

Dufon, M., \& others. (2002). Video recording in ethnographic SLA research: Some issues of validity in data collection. Language Learning \\& Technology, 6(1), 40-59.

Eggins, S. (2004). Introduction to systemic functional linguistics. A \\&c Black.

Gerot, L., \& Wignell, P. (1994). Making sense of functional grammar: An introductory workbook. Antipodean Educational Enterprises Queensland.

Ghani, D. B. A., \& Bin, D. (2015). Upin \\& Ipin: Promoting Malaysian culture values through animation. Historia y Comunicación Social, 20(1), 241-258. https:// doi.org/10.5209/rev_HICS.2015.v20.n1.49558

Gullberg, M. (1998). Gesture as a communication strategy in second language discourse: A study of learners of French and Swedish (Vol. 35). Lund University.

Gullberg, M., \& McCafferty, S. G. (2008). Introduction to gesture and SLA: Toward an integrated approach. Studies in Second Language Acquisition, 30(2), 133-146. https:// doi.org/10.1017/S0272263108080285

Halliday, M. A. K., Matthiessen, C. M. I. M., Halliday, M., \& Matthiessen, C. (2014). An introduction to functional grammar. Routledge. https://doi.org/10.4324/9780203783771

Hopkins, D. (2008). A teachers guide to classroom research. McGraw-Hill.

Jakšić. (2017). Teachers' perception of the application of gestures in the TEFL classroom. Ph.D. thesis University of Zagreb, Zagreb, Croatia.

Kendon, A. (1996). Reflections on the study of gesture. Visual Anthropology, 8(2-4), 121-131. https:// doi.org/10.1080/08949468.1996.9966672

Kita, S. (2000). How representational gestures help speaking. In D. McNeill (Ed.), Language and gesture: Window into thought and action (pp. 162-185). Cambridge, UK: Cambridge Univ. Press https:// doi.org/10.1017/CBO9780511620850.011

Kurniawati, M. W., Anitah, S., \& Suharno, S. (2017). Developing learning Science teaching materials based on scientific to improve students learning outcomes in Elementary School. European Journal of Education Studies.

Kusanagi, Y. (2015). The roles and functions of teacher gesture in foreign language teaching. Temple University.

Kusters, A., \& Sahasrabudhe, S. (2018). Language ideologies on the difference between gesture and sign. Language $\backslash \&$ Communication, 60, 44-63. https://doi.org/10.1016/j.langcom.2018.01.008

Lim, F. V. (2011). A systemic functional multimodal discourse analysis approach to pedagogic discourse. Unpublished Ph. D. Thesis, National University of Singapore, Singapore.

Lim, V. F. (2019). Analysing the teachers use of gestures in the classroom: A systemic functional multimodal discourse analysis approach. Social Semiotics, 29(1), 83-111. https:// doi.org/10.1080/10350330.2017.1412168

Lopez-Ozieblo, R. (2020). Proposing a revised functional classification of pragmatic gestures. Lingua, 247, 102870. https:// doi.org/10.1016/j.lingua.2020.102870

Martinec, R. (2000). Types of process in action. https:// doi.org/10.1515/semi.2000.130.3-4.243

Matthiessen, C. M. I. M. (1999). The system of TRANSITIVITY: an exploratory study of textbased profiles. Functions of Language, 6(1), 1-51. https:// doi.org/10.1075/fol.6.1.02mat 
McNeill, D. (1992). Hand and Mind: What Gestures Reveal About Thought. Chicago: Univ. Chicago Press.

Phiri, M. F. (2016). Effective classroom management by teachers to improve pupils learning process at Nyimba Boarding Secondary School. University of Zambia.

Qinglan, L., Junyan, W., \& Shongshan, H. (2010). Effective classroom management in young learners English teaching. In Retrieved from http://www.celea.org.cn/pastversion/lw/pdf/liqinglan.pdf.

Sato, R. (2019). Examining the effects of gestures in providing oral corrective feedback. Electronic Journal of Foreign Language Teaching, 16(1), 22-33.

Sato, R. (2020). Gestures in EFL classroom: Their relations with complexity, accuracy, and fluency in EFL teachers L2 utterances. System, 89, 102215. https://doi.org/10.1016/j.system.2020.102215

Scherr, R. E. (2008). Gesture analysis for physics education researchers. Physical Review Special Topics-Physics Education Research, 4(1), 10101. https://doi.org/10.1103/PhysRevSTPER.4.010101

Schneiderová. (2014). The effective classroom management in young learners language classes. Masaryk University, Brno, the Czech Republic.

Shearman, S. M., Dumlao, R., \& Kagawa, N. (2011). Cultural variations in accounts by American and Japanese young adults: Recalling a major conflict with parents. Journal of Family Communication, 105-125. https://doi.org/10.1080/15267431.2011.554499

Shin, J. K., \& Crandall, J. A. (2014). Teaching young learners English: From theory to practice. National Geographic Learning/Heinle, Cengage Learning.

Sime, D. (2006). What do learners make of teachers' gestures in the language classroom? IRALInternational Review of Applied Linguistics in Language Teaching, 44(2), 211-230. https://doi.org/10.1515/IRAL.2006.009

Slattery, M., \& Willis, J. (2001). English for primary teachers: A handbook of activities and classroom language (Vol. 1). Oxford University Press.

Smotrova, T. (2017). Making pronunciation visible: Gesture in teaching pronunciation. Tesol Quarterly, 51(1), 59-89. https://doi.org/10.1002/tesq.276

Sukendar, A., Husaini Usman, \& Jabar, C. S. A. (2019). Teaching-Loving-Caring (Asah-AsihAsuh) And Semi-Military Education On Character Education Management. Cakrawala Pendidikan, 38(2), 293-305. https:// doi.org/10.21831/cp.v38i2.24452

Sukirmiyad. (2017). Teaching English to Young Learners Through Indonesian - Translated Songs. The 2nd International Joint Conference on Science and Technology (IJCST). https://doi.org/10.1088/1742-6596/953/1/012236

Thibault, P. J. (2000). The multimodal transcription of a television advertisement: Theory and practice. Multimodality and multimediality in the distance learning age, 31, 1-384.

Widharyanto, B., \& Binawan, H. (2020). Learning style and language learning strategies of students from various ethnics in Indonesia. Jurnal Cakrawala Pendidikan, 39(2), 480492. https:// doi.org/10.21831/cp.v39i2.28173

Wiliam. (2011). Embedded formative assessment. Solution Tree Press: Bloomington, United States.009/JPUD.091. 